Article

\title{
Carbon Dioxide and Methane Formation in Norway Spruce Stems Infected by White-Rot Fungi
}

\author{
Ari M. Hietala ${ }^{1, *}$, Peter Dörsch ${ }^{2}$, Harald Kvaalen ${ }^{1}$ and Halvor Solheim ${ }^{1}$ \\ 1 Norwegian Institute of Bioeconomy Research, P.O. Box 115, Aas NO-1431, Norway; \\ E-Mails: harald.kvaalen@nibio.no (H.K.); halvor.solheim@nibio.no (H.S.) \\ 2 Department of Environmental Sciences, Norwegian University of Life Sciences, P.O. Box 5003, \\ Aas N-1432, Norway; E-Mail: peter.doersch@nmbu.no \\ * Author to whom correspondence should be addressed; E-Mail: ari.hietala@nibio.no; \\ Tel.: +47-6494-9049; Fax: +47-6494-2980.
}

Academic Editor: Mark E. Harmon

Received: 10 July 2015 / Accepted: 17 September 2015 / Published: 22 September 2015

\begin{abstract}
Globally, billions of tons of carbon sequestered in trees are annually recycled back to the atmosphere through wood decomposition by microbes. In Norway, every fifth Norway spruce shows at final harvest infection by pathogenic white-rot fungi in the genera Heterobasidion and Armillaria. As these fungi can mineralize all components of wood, we predicted that they have a significant carbon footprint. Gas samples taken from infected stems were analyzed for $\mathrm{CO}_{2}$ and $\mathrm{CH}_{4}$ concentrations, and wood samples from different parts of the decay columns were incubated under hypoxic $\left(4 \% \mathrm{O}_{2}\right)$ and anoxic laboratory conditions. In spring and summer the stem concentrations of $\mathrm{CO}_{2}$ were generally two times higher in trees with heartwood decay than in healthy trees. For most of the healthy trees and trees with heartwood decay, mean stem concentrations of $\mathrm{CH}_{4}$ were comparable to ambient air, and only some Armillaria infected trees showed moderately elevated $\mathrm{CH}_{4}$. Consistently, low $\mathrm{CH}_{4}$ production potentials were recorded in the laboratory experiment. Up-scaling of $\mathrm{CO}_{2}$ efflux due to wood decay in living trees suggests that the balance between carbon sequestration and emission may be substantially influenced in stands with high frequency of advanced root and stem heartwood decay.
\end{abstract}

Keywords: Armillaria; climate change; forest management; Heterobasidion; wood decay; $\mathrm{CO}_{2} ; \mathrm{CH}_{4}$ 


\section{Introduction}

The global carbon cycle involves exchange of carbon between the atmosphere and marine and terrestrial biospheres, and sediments that include fossil fuels. For the past several decades, burning of fossil fuels and other human activities such as deforestation have produced a net $\mathrm{CO}_{2}$ increase in the atmosphere of $1-2 \mathrm{Pg}\left(=10^{15} \mathrm{~g}\right)$ each year [1]. The increasing atmospheric concentration of $\mathrm{CO}_{2}$ and other greenhouse gases (GHG) has created a measurable increase in global temperature [2].

Future climate changes depend on the magnitude and dynamics of both anthropogenic and natural GHG sources and sinks. Regarding the latter, forests play a major role in carbon cycling as they account for $80 \%$ of terrestrial carbon [3]. With a typical wood density of Scots pine and Norway spruce of $\sim 400 \mathrm{~kg}$ dry matter $/ \mathrm{m}^{3}$ and $50 \%$ carbon content, the carbon stored in $1 \mathrm{~m}^{3}$ of conifer wood equals $\sim 0.73 \mathrm{tCO}_{2}$. In the past few decades, the world's forests have absorbed as much as $30 \%$ of the total anthropogenic $\mathrm{CO}_{2}$ emissions [4]. Thus, maintenance of forest area, reforestation of former agricultural land, increased use of woody products and production of wood biomass for bio-energy are measures included in the climate change mitigation portfolio of the forest sector [2].

Aerobic white-rot fungi are the only organisms able to efficiently mineralize all cell wall components of wood to carbon dioxide and water, and therefore these fungi play a central role in carbon and nitrogen cycling in forests [5]. Disruptions in this cycle are caused by pathogenic microorganisms that attack living trees, reduce tree growth and cause premature tree mortality. These effects in turn reduce the carbon sequestration potential of forests, and accelerate cycling of sequestered carbon. It has been estimated that globally 85 billion tons of carbon are annually recycled back into the atmosphere through the process of lignocellulose decay by microbes [6].

Besides $\mathrm{CO}_{2}$, decomposition of wood can produce $\mathrm{CH}_{4}$, a very potent $\mathrm{GHG}$. Methane in stem wood has traditionally been believed to originate from microbial activity where anaerobic bacteria first degrade wood cell wall components to acetate, formate, $\mathrm{H}_{2}$ and $\mathrm{CO}_{2}$, which are in turn transformed to $\mathrm{CO}_{2}$ and $\mathrm{CH}_{4}$ by co-existing methanogenic archaea [7]. Anaerobic conditions in tree stems that lead to $\mathrm{CH}_{4}$ formation may be associated with bacterial wetwood, especially on poorly-drained soils [8]. Anaerobic or microaerobic conditions can also occur in the heartwood of trees growing on well-drained upland soils to an extent that the mineralization of heartwood by associated decay fungi is hampered $[9,10]$. Under such conditions the intermediate degradation products from lignocellulose decomposition may provide substrates for anaerobic bacteria and archaea, which in turn can accelerate fungal growth by removing their metabolic waste products and by supplying nitrogen through $\mathrm{N}$-fixation [11]. In addition, it has also been proposed that wood decay fungi themselves can produce small amounts of $\mathrm{CH}_{4}$ without the involvement of methanogenic archaea [12].

The white-rot fungi Heterobasidion annosum sensu lato and Armillaria spp. are the most important root and heartwood decaying fungi of Norway spruce, the ecologically dominant conifer that grows on mesophile, well-drained soils in the boreal region. In particular, the Heterobasidion species have benefited from the current forest practice. Primary infection of stands by these fungi takes place through colonization of fresh stumps created during active sporulation of the fungus. In addition, wounds on roots created by mechanical logging during snowless and frost-free periods serve as infection routes. From infected stumps and trees the mycelia of these fungi spread to neighboring trees through root contacts [13]. In managed Norway spruce forests within the Nordic countries, commonly 
every fifth Norway spruce is infected by $H$. annosum s.l. by the time of final harvest $[14,15]$. The heartwood-bound decay columns caused by these species in Norway spruce can rise up to 10-15 $\mathrm{m}$ above ground level at the late stage of infection [13]. Ability to grow under microaerobic conditions is typical to many heartwood associated decay fungi-upon culturing on malt extract agar H. annosum s.l. can grow at oxygen pressures down to $\left(2 \mathrm{~mm} \mathrm{Hg}\right.$ ) [16], which equals $0.26 \mathrm{~atm} \% \mathrm{O}_{2}$. These fungi can also produce anaerobically small amounts of $\mathrm{CO}_{2}$ as a result of alcohol fermentation [17]. At stem base of Norway spruce Heterobasidion species often co-occur with white-rot fungi in the genus Armillaria. When the two coexist, Armillaria species usually occupy outer heartwood, while Heterobasidion is associated with the inner heartwood [18]. Root infection by Armillaria species is often associated with predisposing abiotic conditions such as poorly drained soils [19].

Taking into account the high frequency of extensive stem decay columns caused by H. annosum s.l. in managed Norway spruce stands in Northern Europe, we hypothesized that the emission of $\mathrm{CO}_{2}$ and possibly also $\mathrm{CH}_{4}$ from colonized wood could amount to regionally significant levels. To examine this, we monitored stem $\mathrm{CO}_{2}$ and $\mathrm{CH}_{4}$ concentrations in healthy Norway spruce trees and trees infected by H. annosum s.l. and/or Armillaria spp. over two growing seasons. After completing the field monitoring, the infected tree with the highest concentration of methane was felled and $\mathrm{CO}_{2}$ and $\mathrm{CH}_{4}$ production potentials from defined wood tissues were measured under laboratory conditions.

\section{Materials and Methods}

\subsection{Sites}

Norway spruce (Picea abies) trees were subjected to field monitoring at seven upland stands on

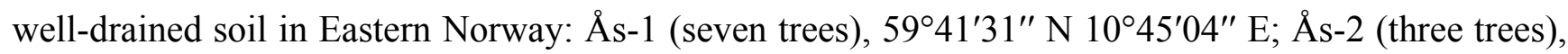

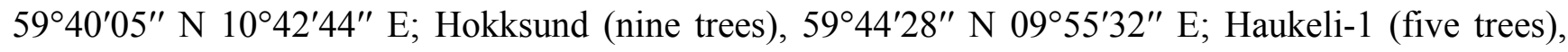

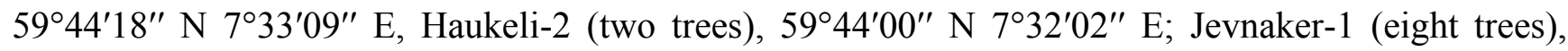

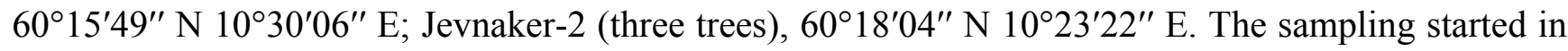
the spring 2013 at $\AA$ s and in July at Hokksund and Haukeli, whereas at Jevnaker the trees were sampled in the summer of 2014. Trees with heartrot were localized by collecting increment cores from stem base. Neighboring trees that showed no signs of decay in the increment core were used as healthy controls. At the Haukeli sites we also sampled three living aspen trees (Populus tremula) with heartrot caused by the white-rot fungus Phellinus tremulae.

\subsection{Sample Trees and Gas Collection}

Tree stems were drilled horizontally at stump level and normally also at breast height with a ten-millimeter-diameter borer, so that the bore hole extended into the pith. For some trees with decay additional drillings were made up to $3.5 \mathrm{~m}$ above stump level. Stainless steel tubes, $100-150 \mathrm{~mm}$ long with $10.5 \mathrm{~mm}$ outer diameter were forced into the holes with a hammer and stopped with butyl rubber septa. Gas samples were taken by a $20 \mathrm{~mL}$ polypropylene syringe equipped with a three-way valve, normally every week in 2013 and at longer time intervals in 2014. Caution was taken to adjust atmospheric pressure (by slipping the plunger) before detaching the syringe to avoid contamination from air. The samples $(15 \mathrm{~mL})$ were transferred to helium-washed, pre-evacuated $12 \mathrm{~mL}$ glass vials 
crimped with butyl rubber septa resulting in an overpressure in the vials to avoid contamination during sample storage.

\subsection{Gas Analysis}

The gas samples were analyzed for $\mathrm{O}_{2}, \mathrm{CO}_{2}, \mathrm{~N}_{2} \mathrm{O}$ and $\mathrm{CH}_{4}$ by gas chromatography (GC, Model 7890, Agilant, Santa Clara, CA, USA) with back flushing and helium (He) as a carrier gas, equipped with a $30 \mathrm{~m}$ wide-bore Poraplot $\mathrm{Q}(0.53 \mathrm{~mm})$ column $\left(38^{\circ} \mathrm{C}\right)$ for separation of $\mathrm{CO}_{2}, \mathrm{~N}_{2} \mathrm{O}$ and $\mathrm{CH}_{4}$ from air and a $60 \mathrm{~m} 5 \AA$ molsieve capillary column $\left(25^{\circ} \mathrm{C}\right)$ for separation of $\mathrm{Ar}, \mathrm{O}_{2}$ and $\mathrm{N}_{2}$. The analytical columns were connected to a thermal conductivity detector (TCD), a flame ionization detector (FID) and an electron capture detector (ECD) for quantification of $\mathrm{CO}_{2}$ and $\mathrm{O}_{2}, \mathrm{CH}_{4}$ and $\mathrm{N}_{2} \mathrm{O}$, respectively. The ECD was run at $375^{\circ} \mathrm{C}$ with $17 \mathrm{~mL} \cdot \mathrm{min}^{-1} \operatorname{argon} / \mathrm{methane}\left[\mathrm{Ar} / \mathrm{CH}_{4}\right]$ [90/10 vol.\%] as make-up gas. The GC was connected to an auto-sampler via a peristaltic pump (Gilson minipuls 3, Middleton, WI, USA) pumping approximately $1.2 \mathrm{~mL}$ gas at 1 atmosphere into two $250 \mu \mathrm{L}$ sampling loops dedicated to each column. Certified standard mixtures of $\mathrm{CO}_{2}, \mathrm{~N}_{2} \mathrm{O}$ and $\mathrm{CH}_{4}$ in Helium (AGA, Norway) were used for calibration.

\section{4. $\mathrm{CH}_{4}$ and $\mathrm{CO}_{2}$ Production Potentials}

Sample tree \#6 ( $\AA$ s), shown to have high stem wood $\mathrm{CH}_{4}$ concentrations in field measurements and appreciable signs of stem base infection by both Heterobasidion annosum s.l. and Armillaria sp., was felled on 5th November 2015. One ten-centimeter-thick stem disc was cut at stump level and one at breast height so that these discs enclosed the bore holes used for in situ profiling of gas concentrations. After visual inspection, three bark-to-heartwood sectors were chosen on each disk for sub-sampling, one of the sectors was taken from the position used for in situ profiling of gas concentrations. Samples $(c a .0 .5 \times 1.0 \times 3.0 \mathrm{~cm})$ were excised with the aid of a band saw from healthy sapwood, a wetwood appearing tissue adjacent to healthy sapwood, a reaction zone tissue formed between healthy sapwood and colonized heartwood, and colonized heartwood (Figure S1). The samples, immediately transferred to sterile $120 \mathrm{~mL}$ serum bottles, had a fresh weight of 4 to $12 \mathrm{~g}$ (depending on sample moisture content). For each sample, two replicate bottles were prepared, one for anoxic, and one for hypoxic incubation. The bottles were crimp sealed with butyl rubber septa, amended with $1 \mathrm{~mL}$ DI water and He-washed ( 5 cycles of evacuation and He-loading with final pressure equilibration). Initially hypoxic bottles received pure $\mathrm{O}_{2}$ to a final headspace concentration of 4 vol\% immediately after He-washing. Altogether, 52 incubation bottles were prepared within $<8 \mathrm{~h}$ since felling.

The bottles were kept in a climate cabinet set at $20{ }^{\circ} \mathrm{C}$. Subsamples $(1 \mathrm{~mL})$ for analysis of $\mathrm{CO}_{2}, \mathrm{O}_{2}$ and $\mathrm{CH}_{4}$ in headspace were taken at hours 40,140, 300 and 550. Gas concentrations were analyzed, as described above, directly in the headspace by using an automatic incubator set up similar to that described in an earlier study [20]. After incubation, the samples were freeze-dried to determine the dry weight. $\mathrm{CO}_{2}$ and $\mathrm{CH}_{4}$ production rates were estimated from increase in concentration over time [ppm h-1] by fitting the product accumulation to a quadratic equation. Rates were recalculated as $\mathrm{mg} \mathrm{CO} 2$ and $\mu \mathrm{g} \mathrm{CH} 4 \mathrm{~m}^{-3} \cdot \mathrm{s}^{-1}$, using headspace volume, sample dry weight and a wood density of 420 $\mathrm{kg} \cdot \mathrm{m}^{-3}$ for Norway spruce [21]. 


\subsection{Estimation of Gas Fluxes from Tree Stems}

Diffusion of gases in wood can be modelled by Fick' law [22]:

$$
\mathrm{M}_{i}=\frac{D 12 A(C 1 i-C 2 i)}{Z}
$$

where $\mathrm{M}_{i}$ is moles of gas $i$ diffusing from compartment 1 to $2, \mathrm{D}_{12}$ the coefficient of diffusion for molecules of type $i, \mathrm{C}_{1 i}$ and $\mathrm{C}_{2 i}$ the concentrations of type $i$ molecules in compartment 1 and 2, respectively, and $\mathrm{Z}$ the distance between compartment 1 and 2 . The diffusion coefficient has been determined for various wood samples and species [23], and found to vary by four orders of magnitude, mostly due to differences in water content of wood. The actual D in a living tree is likely to vary even more due to variability in wood density, humidity, and particularly wood degradation, which alters wood structure, density and humidity. It should be, however, possible to develop a simple model based on Fick's law to obtain a rough estimate for $\mathrm{D}_{12}$ for any given stem section. This requires measurements of the mixing ratios of $\mathrm{CO}_{2}$ and $\mathrm{O}_{2}$ in stems and outside air over time, and validation of the assumption that the respiration consumes one mole of $\mathrm{O}_{2}$ for each mole of $\mathrm{CO}_{2}$ produced:

$$
\mathrm{P}_{\mathrm{CO} 2}=-\mathrm{PO} 2_{2}
$$

where $\mathrm{P}_{\mathrm{CO} 2}$ is the production of $\mathrm{CO}_{2}$ in the stem from time $\mathrm{t}_{1}$ to $\mathrm{t}_{2}$.

This production is the sum of the increase or decrease in the mixing ratio in the stem and the number of moles that have diffused in or out of the stem. Thus, we can write:

$$
\mathrm{P}_{\mathrm{CO} 2}=d C 1 i V+\frac{D 12 A t\left(C^{\prime} 1 i-C^{\prime} 2 i\right)}{Z}
$$

With the assumption that Equation (2) applies, we can write

$$
d C 1 i V+\frac{D 12 A t\left(C^{\prime} 1 i-C^{\prime} 2 i\right)}{Z}=-\left[d C 1 j V+\frac{D 12 A t\left(C^{\prime} 1 j-C^{\prime} 2 j\right)}{Z}\right]
$$

where the subscript $j$ denotes the $j$ th gas, in this case $\mathrm{O}_{2}$, and where $\mathrm{V}$ is the volume of the stem section, $\mathrm{dC}_{1 i}$ is the change in the mixing ratio from time $\mathrm{t} 1$ to $\mathrm{t} 2, \mathrm{t}$ is the time period between $\mathrm{t} 2$ and $\mathrm{t} 1$, $\mathrm{C}^{\prime}{ }_{1 i}$ and $\mathrm{C}^{\prime}{ }_{2 i}$ are the mean mixing ratios of the gases in compartment 1 and 2 during $\mathrm{t}$, and $\mathrm{A}$ and $\mathrm{Z}$ are area and distance as explained for Equation (1).

After accounting for the differences in the molecular masses of $\mathrm{CO}_{2}$ and $\mathrm{O}_{2}$, their diffusivities in wood should be fairly similar. The diffusivity is related to molecular mass according to Graham's law [24].

$$
\delta_{\mathrm{i}}=\left(\frac{m i \times m a}{m i+m a}\right)^{-1 / 2}
$$

where $\mathrm{m}_{\mathrm{i}}$ is the molar mass of the gas in question and $\mathrm{ma}_{\mathrm{a}}$ is the molar mass of air, $28.97 \mathrm{~g} \cdot \mathrm{mol}^{-1}$. Since the latter is obviously different inside and outside the tree, we use the mixing ratios for the inside air to calculate $m_{a}$.

Inserting $\delta_{i}$ and $\delta_{j}$ into Equation (4) and solving this with respect to D we obtain:

$$
\mathrm{D} 12=\frac{d C 1 i V+d C 1 j V}{\frac{A t\left(C^{\prime} 1 i-C^{\prime} 2 i\right)}{Z}-\frac{A t\left(C^{\prime} 1 j-C^{\prime} 2 j\right)}{Z}}
$$

If the gas concentrations are converted to moles per cubic meter and the time unit is days, the unit for $\mathrm{D}_{12}$ becomes $\mathrm{m}^{2} \cdot \mathrm{d}^{-1}$, which can be converted to $\mathrm{cm}^{2} \cdot \mathrm{s}^{-1}$, the standard unit of diffusivity. After D is 
determined in this way, the flux of each gas is calculated according to Equation 1 after taking Graham's law into account.

\subsection{Upscaling of $\mathrm{CO}_{2}$ Fluxes from Decaying Stem Heartwood to Stand and Regional Level}

To explore the impact of $\mathrm{CO}_{2}$ fluxes from decay columns in the heartwood of living trees, we first pooled data from the five trees colonized by H. annosum s.l., since this decay class dominates in the boreal Norway spruce forests in Europe. Upscaling from the tree/site level to county or the whole-country level requires estimates of the difference in carbon emission $\left(\mathrm{E}_{\mathrm{c}}\right)$ between decaying and healthy trees, and how the $E_{c}$ develops with age of the decay. Least square means of the flux data for decay type, site and stem position from July to November 2013 were used to calculate the annual mean flux. Justification for this comes from the fairly symmetrical distribution of monthly mean fluxes [25]. These estimates of the annual mean flux were then plotted against the distances of the sampling points from the ground. For decaying trees a general exponential decline in the flux from the root and upwards was observed, and a simple model was fitted to the least square mean of each fungus and site:

$$
\mathrm{E}_{\mathrm{ci}}=\alpha \exp (-\beta \mathrm{H})+\mathrm{e}_{i}
$$

where $\mathrm{E}_{\mathrm{c} i}$ is the annual flux of $\mathrm{CO}_{2}$ at the $i$ th sampling point, $\alpha$, and $\beta$ are parameters to be estimated, $\mathrm{H}$ is the distance from root to the $i$ th sampling point, and $\mathrm{e}_{i}$ is the residual term. After estimation of the parameters $\alpha$ and $\beta$, the difference in $E_{c}$ between decaying and healthy trees was calculated by inserting the $E_{c}$ values from breast height of healthy trees into

$$
E_{c-h e a l t h y}=\alpha \exp (-\beta 1.3)
$$

Equation (8) was solved with respect to $H$ to give the height at which $E_{c-r o t t e n}=E_{\text {chealthy, which is an }}$ estimate of how high in the stem the decay had spread:

$$
\mathrm{H}_{\mathrm{r}}=\log \left(\mathrm{E}_{\mathrm{c}-\text { healthy/ } \alpha) /-\beta}\right.
$$

where $\mathrm{H}_{\mathrm{r}}$ is the estimated height of the decay column. Thereafter, Ec-healthy was subtracted from the predicted $\mathrm{E}_{c-\text { rotten }}$ values in decaying trees to give estimated surplus $\mathrm{CO}_{2}$ flux, $\mathrm{E}_{\text {cnet, }}$ due to decaying wood. An exponential function, Equation (9), was fitted to $\mathrm{E}_{\text {cnet }}$ with the distance from $\mathrm{H}_{\mathrm{r}}$ to each sampling point $\mathrm{L}_{i}$ as independent variable

$$
\mathrm{E}_{\text {cnetyi }}=\alpha \exp \left(\beta \mathrm{L}_{i}\right)+\mathrm{e}_{i}
$$

Data from the trees studied at Hokksund were pooled, because all sample heights were not represented in each tree, whereas the tree \#7 infected by $H$. annosum s.1. at Ås was analyzed separately.

To calculate the flux for a decaying stem section we first used Behre's stem curve function to find the diameter $d_{r}$ at the top of the rot column $\mathrm{H}_{\mathrm{r}}$ :

$$
\frac{d r}{D}=\frac{L}{(a+b L)}
$$

where $\mathrm{L}$ is the ratio of the distance from the top to $\mathrm{H}_{\mathrm{r}}$ and to $\mathrm{D}$, and $\mathrm{a}$ and $\mathrm{b}$ are coefficients; $\mathrm{b}$ was estimated from the height diameter ratio of the tree and a is simply $1-b$ (a complete description of the method is given in the supplementary material). 
Assuming linear taper from the top of the rot column $\left(\mathrm{H}_{r}\right)$ to the root, the tree circumference of any point below $\mathrm{H}_{\mathrm{r}}$ can be approximated by:

$$
\mathrm{O}_{i}=\pi\left(d_{r}+\mathrm{tL}_{i}\right)
$$

where $\mathrm{O}_{i}$ is the circumference at point $i, d_{r}$ is the diameter at $\mathrm{H}_{\mathrm{r}}$ in meters, and $\mathrm{t}$ is the stem taper in meters per meter, and $\mathrm{L}_{i}$ is the length from $\mathrm{H}_{\mathrm{r}}$ to point $i$.

To find the flux of the whole decaying stem section, Equation (12) is first multiplied with Equation (10).

$$
\mathrm{E}_{\mathrm{s}}=\pi\left(\mathrm{d}_{r}+\mathrm{tL}_{i}\right) \alpha \exp \left(\beta \mathrm{L}_{i}\right)
$$

where $E_{s}$ is the flux in a small section and the other terms as described above.

Integration of Equation (13) gives the total flux in the whole area of the decaying stem section Etots:

$$
\mathrm{E}_{\text {tots }}=\int\left[\alpha \pi \exp \left(\beta \mathrm{L}_{i}\right)\left(\beta\left(\mathrm{d}_{\mathrm{r}}+\mathrm{tL}_{i}\right)+\mathrm{t}\right)\right] / \beta^{2}
$$

The lower limit is at $\mathrm{H}_{\mathrm{r}}$ which is $\mathrm{L}_{\mathrm{r}}=0$ and the upper limit is the distance from $\mathrm{H}_{\mathrm{r}}$ to $\mathrm{L}_{i}$ or to the ground.

To test how the estimated fluxes conformed to biomass loss from rotten wood, we used the wood density profiles measured from a Norway spruce tree with an advanced stem decay column caused by Heterobasidion parviporum [26]. The estimated biomass loss was converted to annual $\mathrm{CO}_{2}$ flux in $\mathrm{kg}$ per square meter by converting the distance between the sampling points to colonization time with the assumption of a constant vertical spread of decay. Huse and Venn [27] reported a mean vertical spread of $18.5 \mathrm{~cm}$ per year for Heterobasidion, but we adjusted this to $17 \mathrm{~cm}$ per year, as one of their experimental trees showed an exceptional spread value of $70 \mathrm{~cm}$ per year. Details of the calculations are given in the supplementary material. Because the density data were given as $\mathrm{kg}$ per $\mathrm{m}^{3}$, the flux was multiplied by the volume of the section and thereafter divided by the area to give the annual flux in $\mathrm{kg} \mathrm{CO} 2$ per $\mathrm{m}^{2}$.

For up scaling, we employed publicly available data from the National Forest Inventory for the eight counties in Eastern Norway (Table S1). The county reports contain tables with information about cutting class, site index, the number of trees per hectare, standing volume, basal area, increment, age, as well as the percentage of wood volume with decay. The decay data were obtained from increment cores that extend from bark to pith at breast height; in presence of decay the volume of the tree would be classified as rotten. The number of sample trees in each stratum can be found by the information on the number of temporary sample plots relative to permanent sample plots and the fact that the sample trees at each temporary plot were sampled with a relascope factor of six. By weighing the various stand variables with the number of sample trees, one can join aggregated data for growth and standing volume with data for decay from the same aggregated strata. The mean age of the decay in the trees can in principle be calculated from the percentages of rotten volume provided that estimates of the annual rate of infection can be obtained. In the county Hedmark there are data for the percent of trees with rot in different diameter classes from two inventories, 1995-1999, and 2000-2004. We used the difference in the un-weighted means of rot frequencies as an estimate of the annual rate of infection, $0.30 \%$. Assuming an equal probability of infection for all diameter classes in a stand, the mean age of the rot is estimated by dividing the percentage of rotten volume by the annual rate of infection. 
To calculate the net loss of $\mathrm{CO}_{2}$ from stem wood due to rot, the current annual volume increments taken from the county inventory reports were converted to gross $\mathrm{CO}_{2}$ fixation in stem wood, $\mathrm{GSP}_{\mathrm{CO} 2}$, by multiplying the assumed average wood density of $420 \mathrm{~kg}$ by 0.51 (carbon ratio in the wood), and the resulting $214.2 \mathrm{~kg}$ by $44 / 12$ (the ratio of the mole weight of $\mathrm{CO}_{2}$ to carbon). The net production NPPCO2 was then calculated as:

$$
\mathrm{NPP}_{\mathrm{CO} 2}=\mathrm{GSP}_{\mathrm{CO} 2}-\mathrm{RP} / 100 \times \mathrm{E}_{\text {tots }}
$$

where RP is the percentage of rotten wood volume taken from the county inventory reports.

The ratio of net $\mathrm{CO}_{2}$ accumulation in stem wood $\mathrm{NPP}_{\mathrm{CO} 2}$ to $\mathrm{GSP}_{\mathrm{CO}}$, the net-to-gross ratio $\mathrm{NG}_{r}$, was used as a common metrics to assess the impact of rot on $\mathrm{CO}_{2}$ fixation at the stand level in the various counties and strata.

\subsection{Statistical Analysis}

For practical reasons a stepwise sampling design was used. The decaying and healthy trees at the Ås site which is close to the laboratory were sampled first; the other sites were sampled later. No trees at the Jevnaker sites showed infection by Armillaria sp. and P. chrysoloma was the only decay fungus present in trees at the Haukeli site. Therefore, to get a more balanced comparison of healthy trees and trees infected with the two most common wood rot fungi in Norway, Armillaria spp. and H. annosum s.l., we used the data from the Ås and Hokksund sites where both fungi were present. All heights were not sampled in all trees, for example the healthy trees were sampled only at stump and breast heights. The sampling design is therefore incomplete and imbalanced and involves repeated measurements of the same trees and heights taken at irregular intervals. A mixed model was used for the analysis of the $\mathrm{O}_{2}$ and $\mathrm{CO}_{2}$ mixing ratios and for the $\mathrm{CO}_{2}$ flux data. Site was considered to be a fixed factor, as the sites were selected based on prior knowledge of edaphic factors that influence decay incidence. Trees within site was considered a random factor, because the trees were selected without any prior knowledge of their gas emissions. A first order autoregressive model was used to model the autocorrelation between repeated measurements from the same sampling point. To test if the $\mathrm{CO}_{2}$ efflux was dependent on the height of the sampling position, the $\mathrm{CO}_{2}$ flux data were log transformed and a regression model with distance from the stump height to the sampling point was fitted to the data by taking other effects into account. The Mixed procedure in the SAS System ${ }^{\mathrm{TM}}$ (SAS Institue, Cary, $\mathrm{NC}$, USA) was used for the analyses, using the default method to compute error degrees of freedom. Normality of the residuals was checked with the normality tests in Univariate procedure in the SAS System $^{\mathrm{TM}}$ and with quantile-quantile (Q-Q) plots. 


\section{Results}

\subsection{Stem $\mathrm{CO}_{2}$ and $\mathrm{CH}_{4}$ Concentrations}

Both healthy Norway spruce trees and trees with heartwood decay showed clear seasonality in stem concentrations of $\mathrm{O}_{2}$ and $\mathrm{CO}_{2}$. No obvious differences were observed between the sites in the seasonality of stem gas concentrations. The stem $\mathrm{O}_{2}$ concentrations generally decreased during growing season (April-September) and showed approximately twofold increase during the dormancy period, whereas the stem $\mathrm{CO}_{2}$ concentrations showed an opposite pattern and started to increase in April/May (Figure 1). The decaying trees showed generally higher $\mathrm{O}_{2}$ concentrations than the healthy trees; these differences were significant $(p<0.0015)$ in October and November. In the period between April and October, the decaying trees showed also generally higher $\mathrm{CO}_{2}$ concentrations than the healthy trees. At stump height these differences were significant in June and July $(p<0.05)$, and at breast height from August to October $(p<0.01)$. Differences in the seasonal fluctuation of stem gas concentrations were observed between healthy and decaying trees: in the decaying trees the minimum concentrations of $\mathrm{O}_{2}$ and maximum concentrations of $\mathrm{CO}_{2}$ occurred in July/August, whereas in healthy trees these cardinal points occurred in September/October.

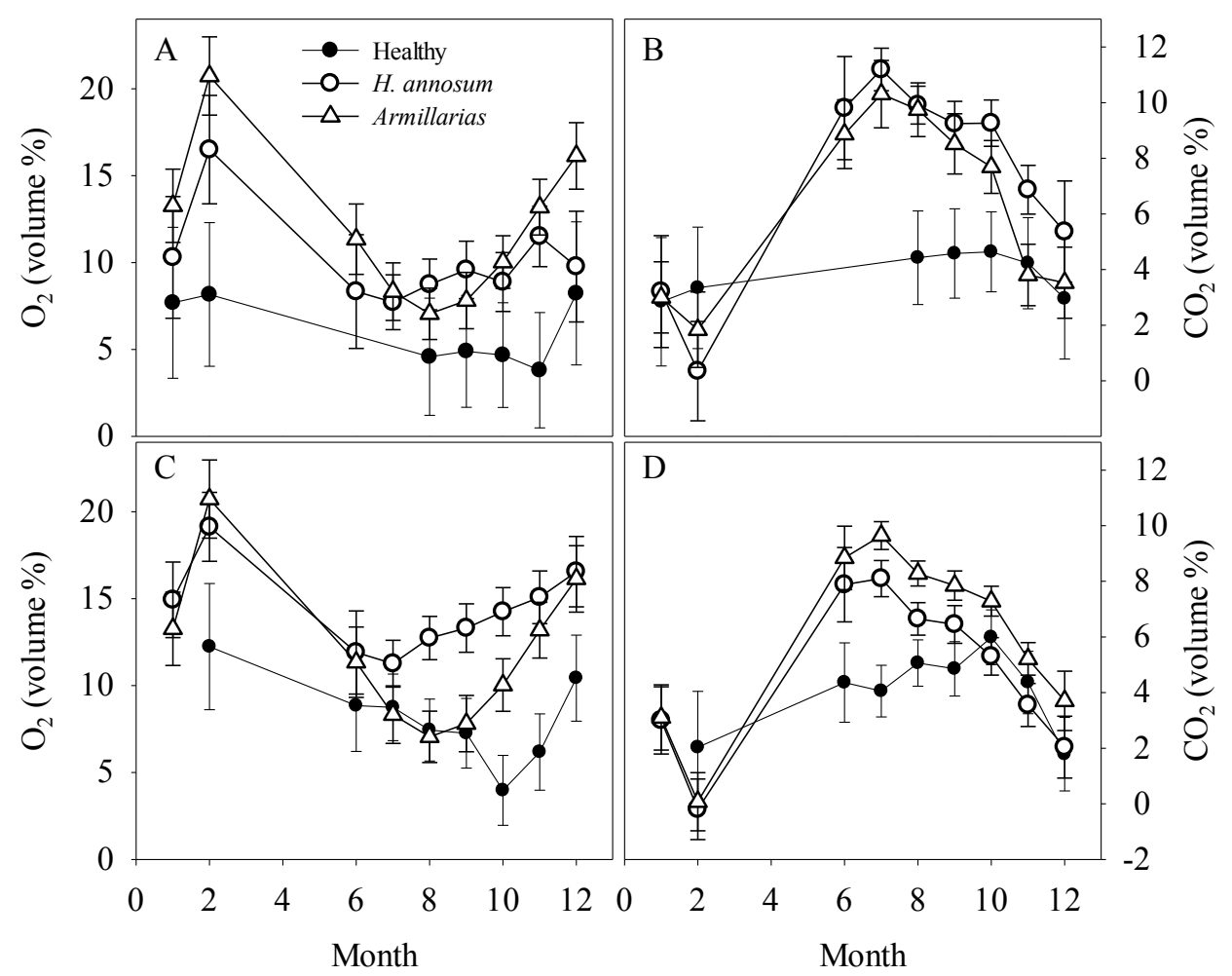

Figure 1. Least square means of monthly $\mathrm{O}_{2}$ concentrations measured at breast height (A), and stump height $(\mathbf{C})$, and the corresponding concentrations of $\mathrm{CO}_{2}(\mathbf{B})$ and $(\mathbf{D})$ in four healthy trees, six trees infected by Heterobasidion annosum s.l. and five trees infected by Armillaria species. Error bars are \pm 1 standard error. The total number of observations is 510. The data are from two sites, Ås and Hokksund, where mean age of the trees was 110 and 54 years, mean tree height 25.6 and $22.9 \mathrm{~m}$, and mean stem diameter at breast height 38.2 and $26.2 \mathrm{~cm}$, respectively. 
For most of the healthy trees and trees with heartwood decay, mean stem concentrations of $\mathrm{CH}_{4}$ were comparable to ambient air ( $\sim 2 \mathrm{ppm})$. Maximum stem concentrations of $\mathrm{CH}_{4}$ were recorded in trees with Armillaria caused heartwood decay, but there was no clear correlation between stem $\mathrm{CH}_{4}$ and $\mathrm{O}_{2}$ concentrations as clearly elevated $\mathrm{CH}_{4}$ levels were observed with $\mathrm{O}_{2}$ concentrations ranging from 1 to 14 vol.\% (Figure 2). Upon tree felling at the end of the field experiment, it was noted that some Norway spruce trees were infected by the white-rot fungus Phellinus chrysoloma; the $\mathrm{CH}_{4}$ levels recorded for these trees were in general similar to those observed in healthy trees and trees infected by $H$. annosum s.l. The trees with heartwood decay could show considerable variation in stem $\mathrm{CH}_{4}$ concentration between different sampling positions with no sampling-height-specific pattern (data not shown). For healthy trees the maximum stem concentration of $\mathrm{CH}_{4}, 17 \mathrm{ppm}$, was recorded for a tree growing right next to a creek. Irrespective of tree condition, the volumetric concentration of $\mathrm{CO}_{2}$ in stems was several thousand times higher than that of $\mathrm{CH}_{4}$ (Table 1).

Table 1. Volumetric ratio of $\mathrm{CH}_{4}$ to $\mathrm{CO}_{2}$ : mean, standard deviation, minimum and maximum of all field samples analyzed.

\begin{tabular}{cccccc}
\hline Treatment & Number of Gas Samples & $\mathbf{C H}_{\mathbf{4}} / \mathbf{C O}_{2}$ & Std & Min & Max \\
\hline Healthy & 94 & $2.8 \times 10^{-4}$ & $4.51 \times 10^{-4}$ & $3.99 \times 10^{-5}$ & $4.64 \times 10^{-3}$ \\
Armillaria $\mathrm{sp}$. & 221 & $2.85 \times 10^{-4}$ & $2.68 \times 10^{-4}$ & $6.39 \times 10^{-10}$ & $9.85 \times 10^{-4}$ \\
H. annosum & 336 & $2.07 \times 10^{-4}$ & $4.17 \times 10^{-4}$ & $1.68 \times 10^{-6}$ & $4.44 \times 10^{-3}$ \\
\hline
\end{tabular}




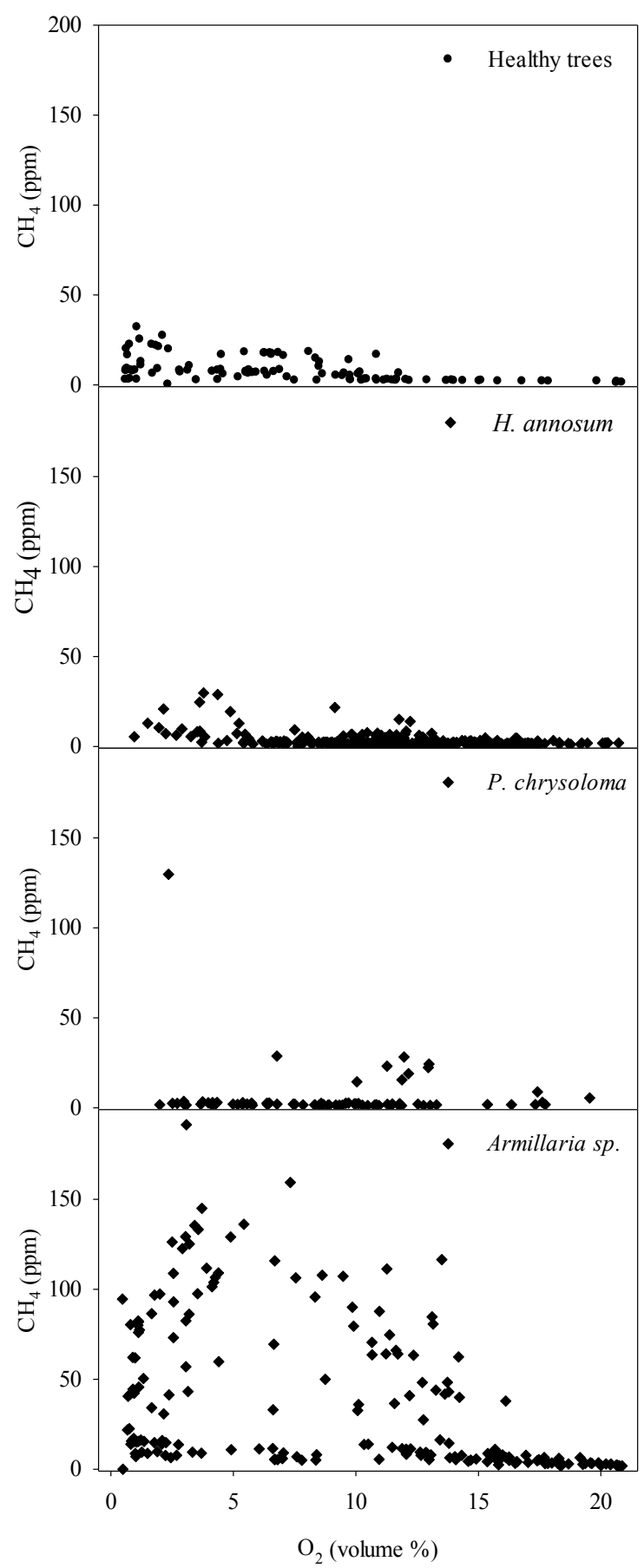

Figure 2. The relationship between in situ concentrations of $\mathrm{CH}_{4}$ and $\mathrm{O}_{2}$ within healthy stems of Norway spruce and stems with heartwood decay caused by Heterobasidion annosum s.1., Phellinus chrysoloma and Armillaria spp. The dataset involves thirtyseven Norway spruce trees from seven sites in South Eastern Norway, and shows values recorded throughout two growing seasons.

Stem concentrations of $\mathrm{CH}_{4}$ and $\mathrm{CO}_{2}$ followed a similar seasonal regulation both in healthy trees and in trees with heartwood decay, as exemplified in Figures 3 and 4. The tree shown in Figure 3 represented an incipient decay caused by Armillaria and restricted to stump level, whereas the tree shown in Figure 4 hosted a four-meter-long decay column caused by Heterobasidion annosum s.l. and co-occurrence of Armillaria at stem base. 


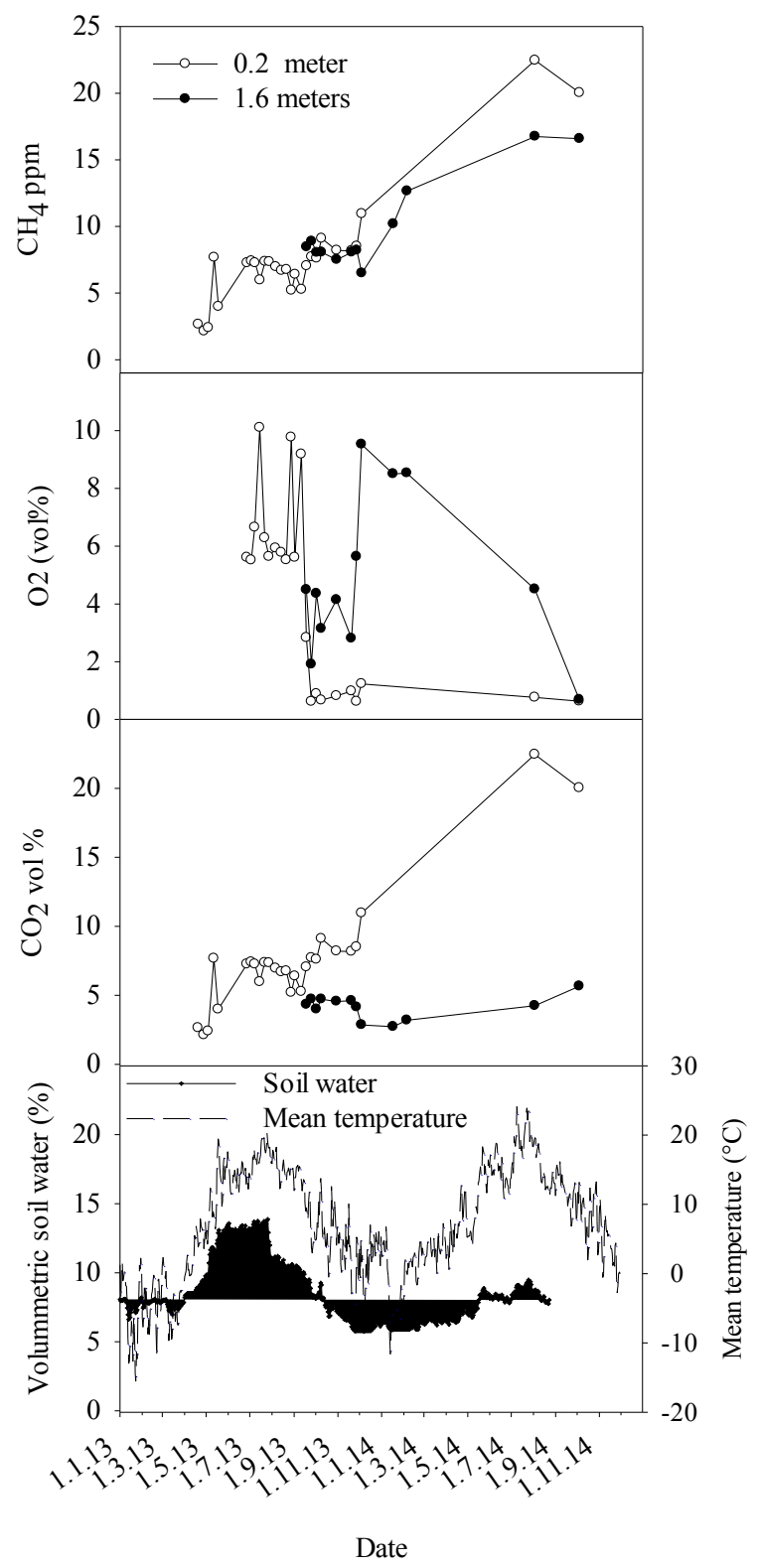

Figure 3. Evolution of in situ concentrations of $\mathrm{CH}_{4}, \mathrm{O}_{2}$, and $\mathrm{CO}_{2}$ at stump level and at breast height within the stem of Norway spruce tree \#2 (age $110 \mathrm{y}$; breast height diameter $40.6 \mathrm{~cm}$; height $27 \mathrm{~m}$ ) at the Ås site. The tree was classified as healthy in 2013 but showed incipient infection by Armillaria sp. at stump height when it was felled in 2014. The lowermost panel shows mean daily air temperature and volumetric soil water content measured at a soil depth between 10 and $80 \mathrm{~cm}$, obtained from Bioforsk Meterological Service at Ås. At stump level significant correlation ( $p$ value $<0.01$ ) was observed between $\mathrm{CH}_{4}$ and $\mathrm{O}_{2}$ (corr. coefficient -0.54$), \mathrm{CO}_{2}$ and $\mathrm{O}_{2}(-0.77)$ and $\mathrm{CH}_{4}$ and $\mathrm{CO}_{2}(0.7)$ stem concentrations. At breast height a significant correlation was observed between $\mathrm{CO}_{2}$ and $\mathrm{O}_{2}(-0.97)$. 


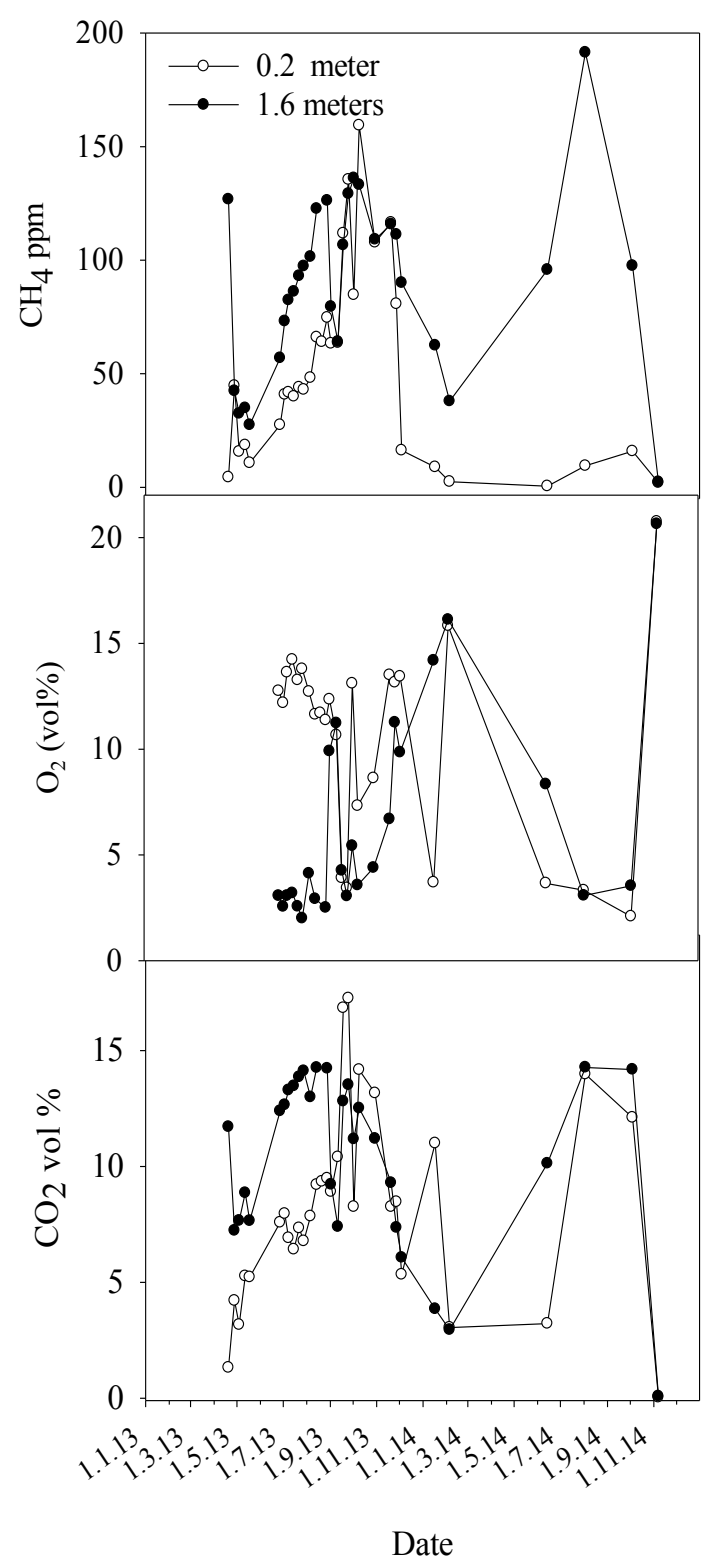

Figure 4. Evolution of in situ concentrations of $\mathrm{CH}_{4}, \mathrm{O}_{2}$, and $\mathrm{CO}_{2}$ at stump level and at breast height within the stem of Norway spruce tree \#6 (age 110 years; breast height diameter $44.5 \mathrm{~cm}$; height $29.1 \mathrm{~m}$ ) at the Ås site. The tree showed combined infection by Heterobasidion annosum s.l. and Armillaria sp. with a four-meter-long decay column in stem heartwood. At stump height with relatively advanced decay in the outermost heartwood, a significant correlation $(p$ value $<0.01)$ was observed between $\mathrm{CO}_{2}$ and $\mathrm{O}_{2}$ (corr. Coefficient $=-0.73$ ) and $\mathrm{CH}_{4}$ and $\mathrm{CO}_{2}(0.64)$ stem concentrations. At breast height with incipient decay a significant correlation was observed between $\mathrm{CH}_{4}$ and $\mathrm{O}_{2}(-0.65)$, $\mathrm{CO}_{2}$ and $\mathrm{O}_{2}(-0.98)$ and $\mathrm{CH}_{4}$ and $\mathrm{CO}_{2}(0.66)$.

\subsection{Tissue-Specific $\mathrm{CO}_{2}$ and $\mathrm{CH}_{4}$ Production Potentials at $20^{\circ} \mathrm{C}$}

Generally, $\mathrm{CO}_{2}$ production rate was significantly higher in hypoxic than in anoxic incubations $(p=0.0008)$ (Figure 5), and significantly higher $(p=0.0001)$ in tissues dissected from stump level than those dissected from breast height. Regarding $\mathrm{CH}_{4}$, no statistically significant difference was 
observed in gas production rate between the sampling heights and the tissue specific samples from the two heights were pooled together for statistical analysis of treatment specific differences. The healthy sapwood and reaction zone showed significantly higher $\mathrm{CH}_{4}$ production under initially hypoxic conditions (4 vol.\%) than under permanently anoxic ones (respective $p$ values 0.0005 and 0.03 ). Under both anoxic and hypoxic conditions, the production rate of $\mathrm{CO}_{2}$ was several orders of magnitude higher than that of $\mathrm{CH}_{4}$ in all the tissue types.

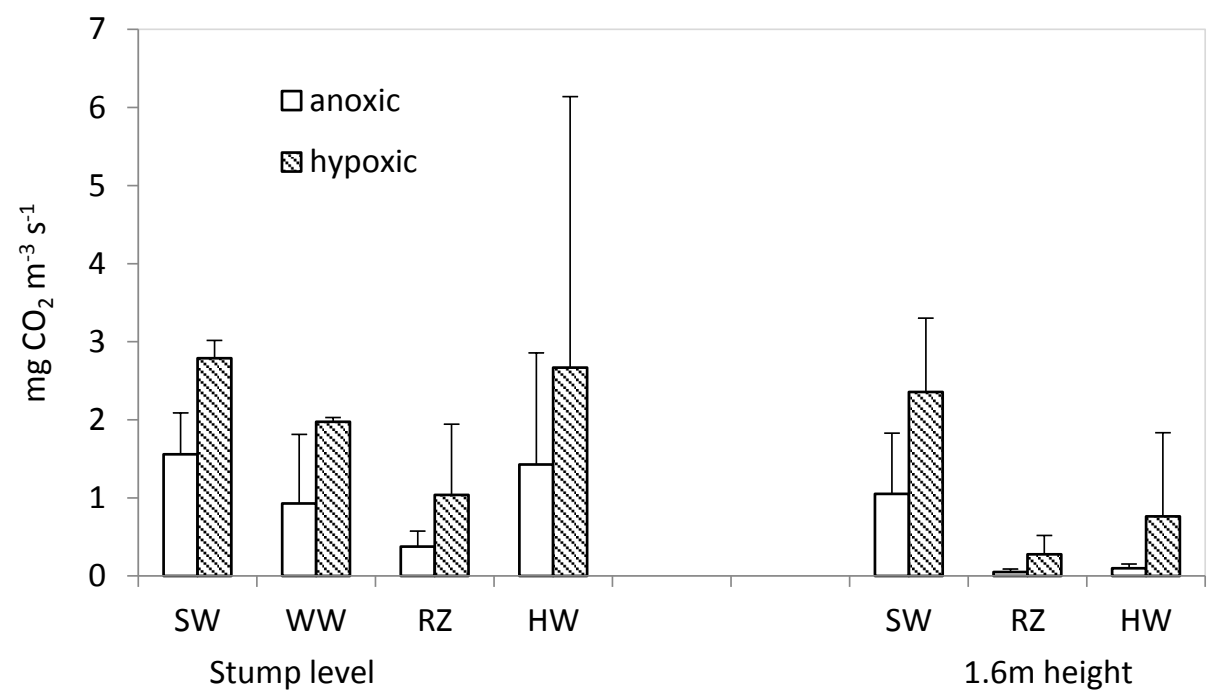

Carbon dioxide production in different tissues

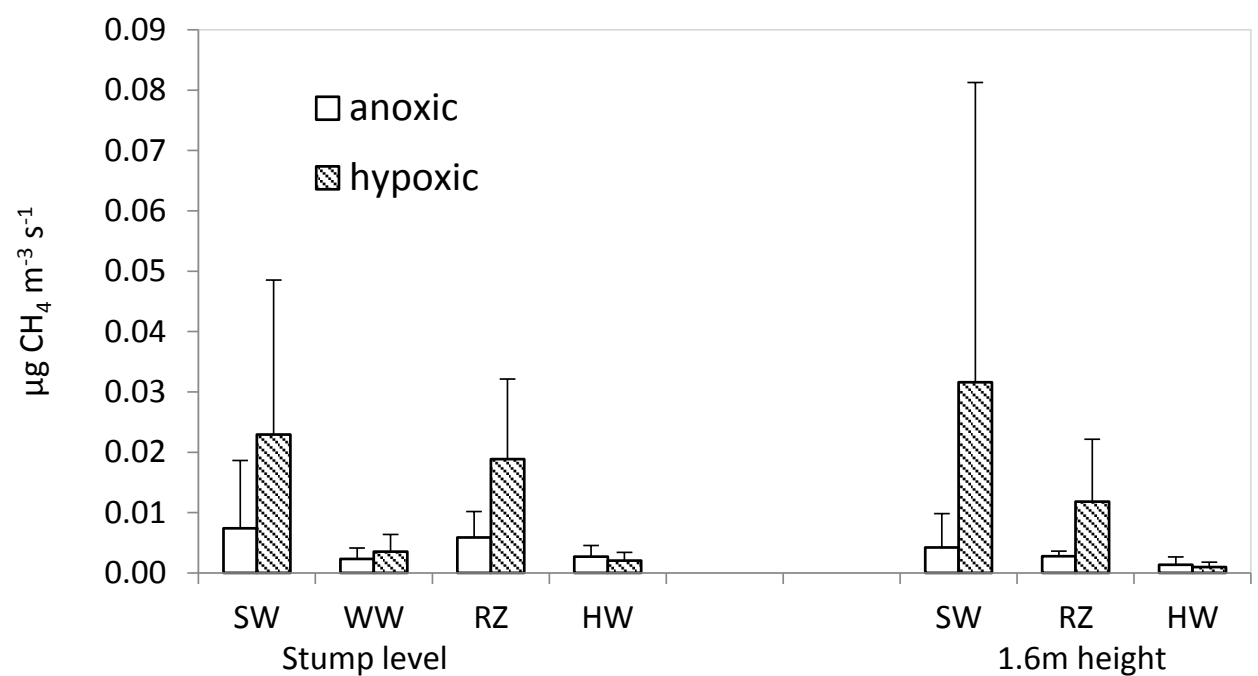

Methane production in different tissues

Figure 5. Average production rates of carbon dioxide and methane in the tissue-type samples dissected from two heights from tree \#6, and incubated for 23 days at anoxic and hypoxic laboratory conditions. SW - healthy sapwood (stump level, $n=3$; breast height, $n=6)$; WW-wetwood $(n=2)$; RZ-uncolonized reaction zone $(n=3)$; HW-colonized heartwood (stump level, $n=5$; breast height, $n=3$ ). Error bars represent \pm one standard deviation. 


\subsection{Upscaling of $\mathrm{CO}_{2}$ Fluxes from Decaying Stem Heartwood to Stand and Regional Level}

In trees infected by $H$. annosum s.l. or Armillaria species, the estimated $\mathrm{CO}_{2}$ fluxes were higher than in the control trees, and the maximum values, found near the ground level, declined exponentially $(p<0.001)$ with the distance from the ground level (Figure 6A-D). The highest $\mathrm{CO}_{2}$ flux observed in a tree with heartwood decay was ten to twenty times higher than in the control trees (Figure 6D). There was also a non-significant tendency of lower $\mathrm{CO}_{2}$ fluxes at 1.3 meter height than at stump level in the control trees (Figure 6).

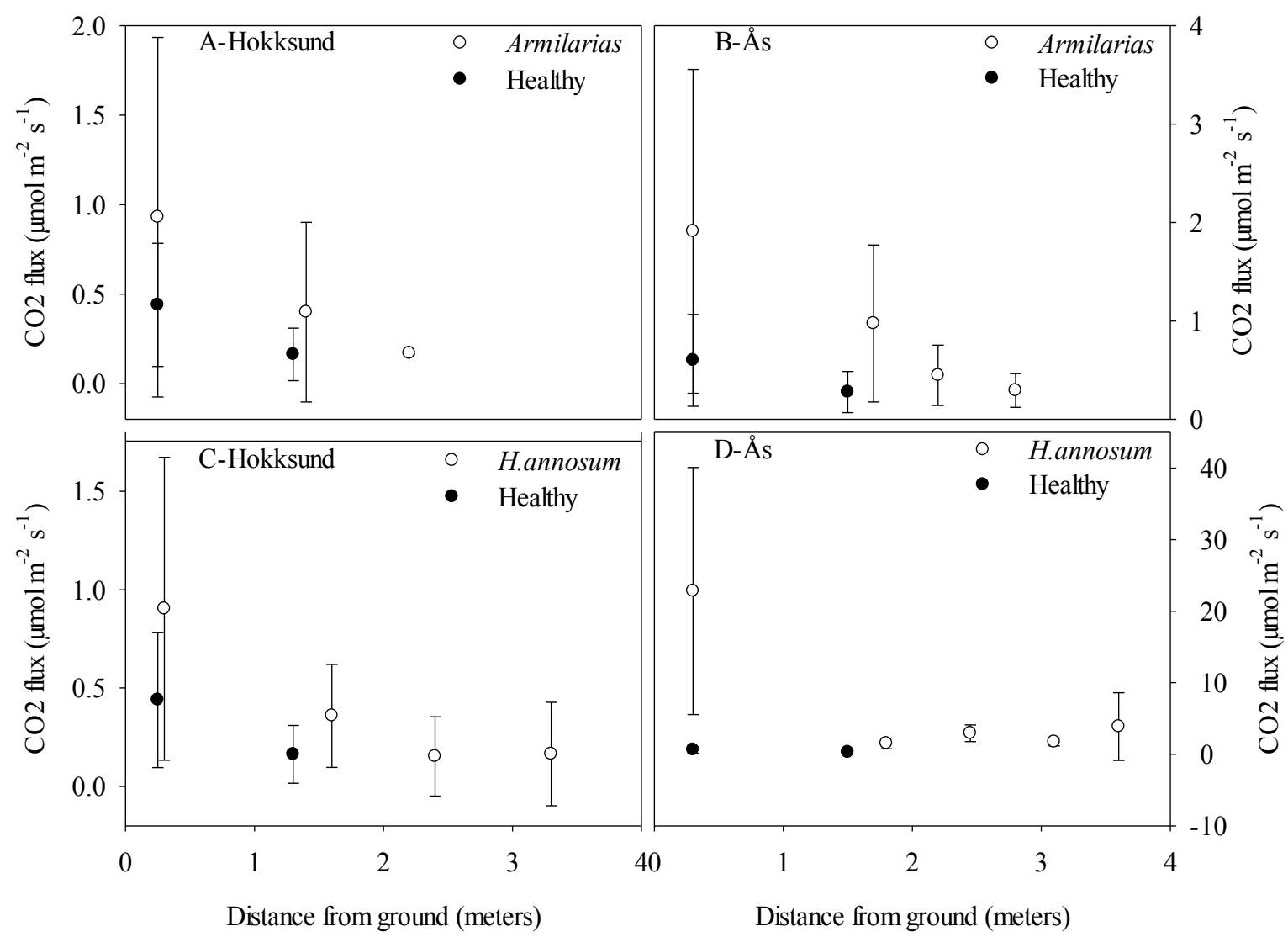

Figure 6. Estimated $\mathrm{CO}_{2}$ fluxes at different stem heights in healthy trees and trees infected with Armillaria species or $H$. annosum s.l. Up to 80 gas samples per category were collected in the period between July and November in 2013. The means are weighted with the length of the sampling period, error bars are \pm one standard deviation. At Ås there were two healthy trees, four Armillaria infected trees and one $H$. annosum s.l. infected tree. For Hokksund, the corresponding tree numbers were two, one and five, respectively.

$\mathrm{NPP}_{\mathrm{CO} 2}$ was only slightly influenced by decay in stands with low rot percentage (Figure 7), irrespective of the estimation method. When the stand rot percentage was above 15 percent, the net to gross ratio, $\mathrm{NG}_{\mathrm{r}}$, declined sharply with the flux based method both with parameter estimates from the five trees at Hokksund and with the one tree at Ås. The $\mathrm{NG}_{\mathrm{r}}$ estimates based on the wood density loss in one tree were little influenced by increasing stand rot percentage. The $\mathrm{NG}_{\mathrm{r}}$ values shown in Figure 7 are from samples where the mean length of the stem decay column is below six meters in order to keep this parameter close to the limits of the decay column heights observed in the trees used for the flux 
based model. Only in one sample from Telemark (standcutting class 3, site class 2) was the estimated mean decay column height larger, 7.3 meters and the stand rot percentage 28 percent. In this sample the flux based method produced $\mathrm{NG}_{\mathrm{r}}$ of about -2.5 , implying that the stand had a net loss of $\mathrm{CO}_{2}$. The density based estimate in the same sample produced a modest $\mathrm{NG}_{\mathrm{r}}$ reduction from 1 to 0.96 .

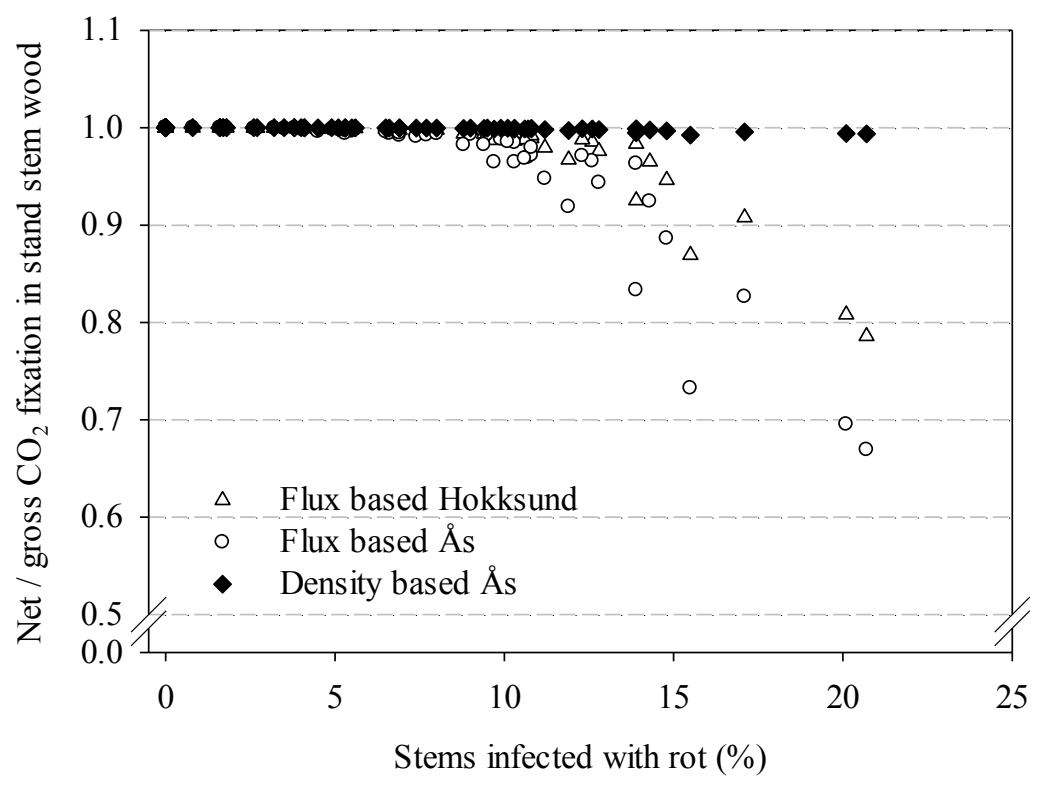

Figure 7. Ratio of net-to-gross $\mathrm{CO}_{2}$ fixation per hectare in the stem wood at Heterobasidion infested Norway spruce stands, as estimated from $\mathrm{CO}_{2}$ fluxes and rot prevalence in tree stems; see text for explanation of the method. The flux based estimates are from the five Heterobasidion infected trees monitored at Hokksund and the one monitored at Ås. Wood density estimates are based on stem section data of one Norway spruce tree that showed an extensive stem decay column caused by Heterobasidion parviporum in our previous study [26] (tree \#9).

\section{Discussion}

As a result of $\mathrm{CO}_{2}$ released by respiring living cells and barriers to diffusion of gases in bark and xylem, the concentration of $\mathrm{CO}_{2}$ in tree stems is strongly elevated above ambient [28]. The stem concentrations of $\mathrm{CO}_{2}$ and the seasonal dynamics now recorded in healthy trees are in line with previous studies for Norway spruce [29] and other tree species [28]. For trees infected by Heterobasidion annosum s.1. and Armillaria species, the most common white-rot fungi associated with heartwood of Norway spruce in boreal forests, the stem concentrations of $\mathrm{CO}_{2}$ in spring and summer were generally two times higher than those observed for trees without any decay in heartwood. To the best of our knowledge, this is the first report about seasonal fluctuation in gas concentrations in stems of living trees affected by decay. The maximum stem concentrations of $\mathrm{CO}_{2}$ now recorded for decaying trees, $>20 \%$, are two-fold higher than those observed in summertime for saprotrophic fungal species associated with wood logs and stumps [30].

While the source of the stem gases was not identified by isotope analysis in our study, most of the surplus of $\mathrm{CO}_{2}$ in stems of trees with heartwood decay obviously resulted from microbial respiration and mineralization of wood; white-rot fungi are the only organisms that are able to efficiently degrade 
all structural components of wood, the recalcitrant lignin included [31]. However, during the early phase of host/pathogen interaction, when an antifungal polyphenol-rich host defense tissue forms at the interface between sapwood and pathogen colonized heartwood [32], part of the excess $\mathrm{CO}_{2}$ could also be derived from increased use of tree's energy reserves to build and reinforce this reaction zone. Another point worth noting is the seasonally earlier peaking of stem $\mathrm{CO}_{2}$ concentrations in the decaying trees in comparison to healthy trees. Considering that heartwood is probably thermally insulated by bark and sapwood, and the fact that the optimal growth temperature of Heterobasidion species and many other heartwood associated decay fungi is above $20{ }^{\circ} \mathrm{C}$ [13], we presume this difference is due to peaking of fungal respiration during the warmest time of the summer.

When considering the impact of heartrot in living trees on carbon sequestration and emission at tree and stand level, several factors need to be taken into account. First, the growth of the tree may be reduced as a result of root decay and reduction of the conductive sapwood in stem due to extensive heartrot, these eventually resulting in premature death of the tree. Secondly, the decay caused by white-rot fungi may not advance at a linear rate; the elevated $\mathrm{O}_{2}$ levels observed at stump height in many of the trees with heartwood decay, originating either from increased diffusion of air into xylem due to breakage of decayed main roots by wind rocking and/or transport of oxygen to decomposing heartwood from soil by hyphae or rhizomorphs, can be expected to accelerate degradation of lignin, the rate limiting step during incipient wood decay. Finally, there is uncertainty about the efflux of $\mathrm{CO}_{2}$ to the atmosphere, as part of the $\mathrm{CO}_{2}$ formed within stems and branches can be fixed by bark or needle photosynthesis [28].

Our $\mathrm{CO}_{2}$ flux estimates amounted to about 70 percent of the values given in a recent study [25] for healthy trees during the month July to November. There was large temporal variation in the estimates of radial $\mathrm{CO}_{2}$ diffusion coefficients in the estimated fluxes, as shown by the large standard deviations. However the values of the coefficients (Table S2) were generally within the range that has been determined experimentally [23]. Experimental determination showed that the diffusion coefficients in the radial direction vary by four orders of magnitude mostly in response to wood water content. Thus, large variability in the fluxes from trees in vivo is to be expected. The fairly close agreement with the data from a recent Norway spruce study [25] suggest, that the method developed here could be suitable for estimating gas fluxes from stem mixing ratios.

It is noteworthy that the maximum decay frequency of $20 \%$ used in our models (Figure 7) corresponds to the observed average decay frequency caused by $H$. annosum s.l. in managed Norway spruce forests by the time of final harvest, and that in individual Norway spruce stands the decay frequency can be above 50\% [14,15]. The up-scaling of $\mathrm{CO}_{2}$ efflux from Heterobasidion caused decay to the stand level based on aggregated data for decay frequency and annual volume growth from national forest inventories suggests that root and heartwood decay in living Norway spruce trees can cause a substantial loss of carbon. In stands with low annual growth and high decay frequency the carbon loss due to mineralization of lignocellulose to $\mathrm{CO}_{2}$ could be sufficient to turn the trees from a carbon sink to a source. There are many uncertainties with the flux estimates and the assumptions about the infection and spread rates. For practical reasons, we could not start sampling at the same time at all sites, and some additional trees and heights were also included as the sampling progressed. To minimize the potentially confounding effects of differential sampling on the flux calculations, we chose to use samples only from the sites Ås and Hokksund and the months July to November in 2013. 
This half-year period is obviously a very limited time to make strong inferences about biological processes that can vary with temperature, humidity and other factors. The results from the flux based and the density based up-scaling differed considerably; the former suggested that wood decay has a large impact on net $\mathrm{CO}_{2}$ fixation, while the latter suggested a minimal effect. The difference could be due to systematic errors in both methods or due to real variability between sites, years, and trees. Regarding the latter, Huse and Venn [27] observed more than ten-fold difference in vertical spread of $H$. annosum between different trees, and thus large variation in the biomass breakdown rate and $\mathrm{CO}_{2}$ fluxes between trees is quite possible. Therefore the estimates presented in Figure 7 serve above all as an illustration of a potential effect. It is worth noting that both the $\mathrm{CO}_{2}$ flux based estimates and the wood density based estimates decline exponentially with the distance away from stem base where the infection is oldest, this implying that biomass loss accelerates with the duration of the infection. However, when most of the substrate in the heartwood has been consumed, the $\mathrm{CO}_{2}$ flux should eventually decline. Consequently, to obtain reliable carbon budgets for young and mature forest stands, the frequency, type and stage of decay in living trees need to be taken into account.

Regarding methane, healthy Norway spruce and trees with heartwood decay caused by Heterobasidion annosum s.l. showed comparable stem concentrations of $\mathrm{CH}_{4}$, around $30 \mathrm{ppm}$ at maximum. Contrastingly, trees infected by Armillaria species showed frequently 3-4 times as high $\mathrm{CH}_{4}$ levels. We are not aware of any earlier reports about stem concentrations of $\mathrm{CH}_{4}$ in Norway spruce or any other tree species infected by Heterobasidion and Armillaria spp., fungi able to infect a wide range of conifer and broadleaved trees. As proposed in earlier studies, under microaerobic or anaerobic conditions, intermediate degradation products from fungal degradation of lignocellulose may provide substrates for bacteria and archaea $[9,10]$, which in turn can accelerate fungal growth by removing their metabolic waste products and by enriching the substrate through $N$-fixation [11]. The apparent lack of correlation between stem $\mathrm{CH}_{4}$ and $\mathrm{O}_{2}$ concentrations in trees with elevated $\mathrm{CH}_{4}$ levels is noteworthy, and is probably due to the utilized point measurements, which profile the composition of gas diffusion stream that includes also the $\mathrm{CH} 4$ produced at anaerobic microsites. When comparing the differences in ecological range and behavior between Armillaria and Heterobasidion species, Shaw [33] stressed that Armillaria species are frequently associated with water-logged trees, have the ability to transport oxygen in the air channels of rhizomorphs that are commonly formed in decayed heartwood, and that their mycelial growth is highly stimulated by ethanol, an anaerobic microbial but also plant fermentation product. These features may suggest that Armillaria species are better adapted to grow and feed under anaerobic conditions than Heterobasidion species. The potential interplay between anaerobic bacteria and archaea, and Armillaria species at anaerobic/aerobic sub-surfaces of wood tissues upon lignocellulose decomposition remains to be clarified.

Similarly to the low mixing ratios of $\mathrm{CH}_{4}$ and $\mathrm{CO}_{2}$ recorded within Norway spruce stems, a low production rate of $\mathrm{CH}_{4}$ in comparison to that of $\mathrm{CO}_{2}$ was observed in the laboratory experiment, where selected tissue types were incubated under anoxic or hypoxic conditions. At an upland site in temperate forest, mean stem concentrations of $\mathrm{CH}_{4}$ in three broadleaved trees (red maple, red oak, black birch) during the growing season were above 15,000 ppm, whereas the conifer Pinus strobus showed only negligible stem concentrations of $\mathrm{CH}_{4}$ and a mean production rate of $0.067 \mu \mathrm{g}$ $\mathrm{CH} 4 \mathrm{~m}^{-3} \cdot \mathrm{s}^{-1}$ under laboratory incubation [34], a level essentially similar to that observed for healthy Norway spruce wood in the present study. Covey and coworkers [34] proposed that the high $\mathrm{CH}_{4}$ 
levels in broadleaved trees originated from methanogenesis by archaea within the tree stem and that microbial infection of living trees might result in substantial biogenic production of $\mathrm{CH}_{4}$ also in upland forests. In the study of Mukhin and Voronin [35] substantially higher production rate of $\mathrm{CH}_{4}$ from decaying birch and pine wood than those recorded for Norway spruce in the laboratory experiment of the current study, which they attributed to progressive wood degradation by decay fungi and anaerobic microbes. In contrast to these studies, our data does not indicate that Norway spruce, when growing on well-drained stands and whether healthy or showing heartwood decay caused by white-rot fungi, plays any significant role in biogenic in situ production of $\mathrm{CH}_{4}$, or in its transport from a biogenic source in soil. The reasons for the large variation in stem $\mathrm{CH}_{4}$ concentrations between different tree species growing on well-drained soils remain to be clarified but this variation may relate to tree-species specific differences in the amount of xylem-associated anaerobic microsites that support methanogenic archaea.

Regarding the pattern of $\mathrm{CH}_{4}$ production among different wood tissue types determined in the laboratory experiment, healthy sapwood and reaction zone produced clearly more $\mathrm{CH}_{4}$ under hypoxic conditions than anoxic ones. The observed anoxic production of $\mathrm{CH}_{4}$ in these tissues does not preclude a biogenic origin but the elevated $\mathrm{CH}_{4}$ production rate under hypoxic conditions rather points towards production through a chemical mechanism. Several studies [36-38] have shown production of $\mathrm{CH}_{4}$ from plants under stress and provided evidence that it could be derived from action of free radicals on plant cell wall components such as pectin. A similar mechanism could account for the now recorded methane production from healthy sapwood. One could envisage that $\mathrm{CH}_{4}$ generation from trees through such a mechanism could be the highest in timber logged during spring, summer and autumn when the wood is not frozen. However, if the magnitude of $\mathrm{CH}_{4}$ production in logged timber is at a similar level as now observed in the laboratory experiment, the production rate of $\mathrm{CH}_{4}$ through a biochemical mechanism in timber of Norway spruce can also be considered as insignificant.

\section{Conclusions}

Our motivation to carry out this study was the prediction that emission of $\mathrm{CO}_{2}$ and possibly also $\mathrm{CH}_{4}$ from decaying heartwood in living Norway spruce trees could amount to regionally significant levels, especially when considering that on average every 4th tree is affected by root and stem decay in most mature stands of Norway spruce [14]. Due to fungal respiration, the recorded stem $\mathrm{CO}_{2}$ concentrations could be over two-fold higher in trees with heartwood decay in comparison to healthy trees. In contrast to $\mathrm{CO}_{2}$, the low stem concentrations of $\mathrm{CH}_{4}$ recorded in both healthy and decaying trees can be considered as insignificant. The performed up-scaling of $\mathrm{CO}_{2}$ efflux measurements from six Norway spruce trees with heartwood based decay columns caused by Heterobasidion annosum s.l. suggests that the balance between carbon sequestration and emission could be significantly influenced at stands with high frequency of advanced root and stem heartwood decay. However, large scale studies with more intensive measuring of $\mathrm{CO}_{2}$ fluxes from decaying heartwood are warranted to obtain robust estimates about the impact of fungal mineralization of wood on carbon budgets in Norway spruce stands. Our hope is that the pilot up-scaling exercise carried out now will stimulate further studies on this poorly explored topic. 


\section{Acknowledgments}

This study was supported by Utviklingfondet for skogbruk and Skogtiltaksfondet. We thank Trygve Fredriksen, Monica Fongen, M.Sc. Barbara Rzepka and M.Sc. Katarzyna Wasak for assistance in sampling and the owners of the experimental forests, Norwegian University of Life Sciences, Norwegian Forest and Landscape Institute, Per Aker, Harald Kvaalen, Per Olimb and Johann Ingvald Klute.

\section{Author Contributions}

Harald Kvaalen, Ari Hietala and Halvor Solheim came up with the original research idea and prepared the grant application that enabled the study. The research was designed by all authors. Harald Kvaalen and Halvor Solheim contacted forest owners. In addition to persons named in the acknowledgments, gas samples from living trees were collected by Halvor Solheim and Harald Kvaalen. Collection of samples for the laboratory incubation experiment was carried out by Harald Kvaalen and Ari Hietala. Laboratory analyses were conducted by Peter Dörsch and data analyses by Peter Dörsch and Harald Kvaalen. The manuscript was written by Ari Hietala and Harald Kvaalen, and supported by the other two authors.

\section{Conflict of Interest}

The authors declare no conflict of interest.

\section{References}

1. Keeling, C.D.; Whorf, T.P.; Wahlen, M.; van der Plicht, J. Interannual extremes in the rate of rise of atmospheric carbon dioxide since 1980. Nature 1995, 375, 666-670.

2. Intergovernmental Panel on Climate Change (IPCC). IPCC Fourth Assessment Report in Summary for Policymakers; IPCC: Geneva, Switzerland, 2007.

3. Dixon, R.K.; Brown, S.; Houghton, R.A.; Solomon, A.M.; Trexler, M.; Wisneiwski, J. Carbon pools and flux of global forest ecosystems. Science 1994, 263, 185-190.

4. Pan, Y.; Birdsey, R.A.; Fang, J.; Houghton, R.; Kauppi, P.E.; Kurz, W.A.; Phillips, O.L.; Shvidenko, A.; Lewis, S.L.; Canadell, J.G.; et al. A large and persistent carbon sink in the world's forests. Science 2011, 333, 988-993.

5. Ralph, J.P.; Catcheside, D.E.A. Biodegradation by White-Rot Fungi. In The Mycota X. Industrial Applications; Osiewacz, H.D., Ed.; Springer-Verlag: Berlin Heidelberg, Germany, 2002, pp. 303-326.

6. Cowling, E.B. Structural features of cellulose that influence its susceptibility to enzymatic hydrolysis. In Advances in Enzymatic Hydrolysis of Cellulose and Related Materials; Reese, E.T., Ed.; Pergamon Press: New York, NY, USA, 1963; pp. 1-32.

7. Stams, A.J.M.; Plugge, C. The Microbiology of Methanogenesis. In Methane and Climate. Change; Reay, D., Smith, P., Eds.; Earthscan: London, UK, 2010; pp. 14-26.

8. Zeikus, J.G.; Ward, J.C. Methane Formation in Living Trees: A Microbial Origin. Science 1974, 184, 1181-1183. 
9. Jensen, K.F. Oxygen and carbon dioxide affect the growth of wood-decaying fungi. For. Sci. 1967, $13,384-389$.

10. Schmidt, O. Wood and Tree Fungi: Biology, Damage, Protection and Use, 1st ed.; Springer-Verlag: Berlin Heidelberg, Germany, 2006

11. Beckmann, S.; Kruger, M.; Englelen, B.; Gorbushina, A.; Cypionka, H. Role of bacteria, archaea and fungi involved in methane release in abandoned coal mines. Geomicrobiol. J. 2011, 28, $347-358$.

12. Lenhart, K.; Bunge, M.; Ratering, S.; Neu, T.R.; Schüttmann, I.; Greule, M.; Kammann, C.; Schnell, S.; Müller, M.; Zorn, H.; et al. Evidence of methane production by saprotrophic fungi. Nat. Commun. 2012, 3, 1046.

13. Woodward, S.; Hüttermann, A.; Karjalainen, R.; Stenlid, J. Heterobasidion Annosum-Biology, Ecology, Impact, and Control; CAB International: Oxford, UK, 1998; pp. 589.

14. Huse, K.; Venn, K.; Solheim, H. Stump inventory of root and butt rots in Norway spruce cut in 1992. (In Norwegian with English summary) Rapp. Skogforsk 1994, 23, 1-26.

15. Tamminen, P. Butt-rot in Norway spruce in southern Finland. Commun. Inst. For. Fenn. 1985, $127,1-52$.

16. Gundersen, K. Growth of Fomes annosus under reduced oxygen pressure and the effect of carbon dioxide. Nature 1961, 190, 649.

17. Korhonen, K.; Stenlid, J. Biology of Heterobasidion annosum. In Heterobasidion Annosum: Biology, Ecology, Impact and Control; Woodward, S., Stenlid, J., Karjalainen, R., Hütterman, A., Eds.; CAB International: Oxford, UK, 1998; pp. 43-70.

18. Greig, B.J.W. Fomes annosus (Fr.) Cke. and other root-rotting fungi in conifers on ex-hardwood sites. Forestry 1962, 35, 164-182.

19. Wargo, P.M.; Harrington, T.C. Host stress and Susceptibility. In Armillaria Root Disease; Agriculture Handbook No. 691; Shaw, C.G., III, Kile, G.A., Eds.; Forest Service, United States Department of Agriculture: Washington, DC, USA, 1991, pp. 88-101.

20. Molstad, L.; Dörsch, P.; Bakken, L.R. Robotized incubation system for monitoring gases $\left(\mathrm{O}_{2}\right.$, NO, $\mathrm{N}_{2} \mathrm{O}, \mathrm{N}_{2}$ ) in denitrifying cultures. J. Microbiol. Meth. 2007, 71, 202-211.

21. Molteberg, D.; Høibø, O. Modelling of wood density and fibre dimensions in mature Norway spruce. Can. J. For. Res. 2007, 37, 1373-1389.

22. Petty, J.A. Diffusion of non-swelling gases through dry conifer wood. Wood Sci. Tech. 1973, 7, 297-307.

23. Sorz, J.; Hietz, P. Gas diffusion through wood: Implications for oxygen supply. Trees Struct. Funct. 2006, 20, 34-41.

24. Massman, W.J. A review of the molecular diffusivities of $\mathrm{H}_{2} \mathrm{O}, \mathrm{CO}_{2}, \mathrm{CH}_{4}, \mathrm{CO}, \mathrm{O}_{3}, \mathrm{SO}_{2}, \mathrm{NH}_{3}$, $\mathrm{N}_{2} \mathrm{O}$ and $\mathrm{NO}_{2}$ in air, $\mathrm{O}_{2}$ and $\mathrm{N}_{2}$ near STP. Atmos. Environ. 1998, 32, 1111-1127.

25. Tarvainen, L.M; Räntfors, M.; Wallin, G. Vertical gradients and seasonal variation in stem $\mathrm{CO}_{2}$ efflux within a Norway spruce stand. Tree Physiol. 2014, 34, 488-502.

26. Hietala, A.M.; Nagy, N.E.; Steffenrem, A.; Kvaalen, H.; Fossdal, C.G.; Solheim, H. Spatial patterns in hyphal growth and wood degradation within Norway spruce stems colonized by the pathogenic white-rot fungus Heterobasidion parviporum. Appl. Environ. Microbiol. 2009, 75, 4069-4078. 
27. Huse, K.; Venn, K. Vertical spread of Heterobasidion annosum Bref. Isolates inoculated in stems of Picea abies (L.) Karst. Medd. Skogforsk 1993, 46, 1-14.

28. Teskey, R.O.; Saveyn, A.; Steppe, K.; McGuire, M.A. Origin, fate and significance of $\mathrm{CO}_{2}$ in tree stems. New Phytol. 2008, 177, 17-32.

29. Eklund, L. Endogenous levels of oxygen, carbon dioxide and ethylene in stems of Norway spruce during one growing season. Trees Struct. Funct. 1990, 4, 150-154.

30. Hintikka, V.; Korhonen, K. Effects of carbon dioxide on the growth of lignicolous and soil-inhabiting Hymenomycetes. Commun. Inst For. Fenn. 1970, 62, 1-22.

31. Hatakka, A. Lignin-modifying enzymes from selected white-rot fungi: Production and role in lignin degradation. FEMS Microbiol. Rev. 1994, 13, 125-135.

32. Oliva, J.; Camarero, J.J.; Stenlid, J. Understanding the role of sapwood loss and reaction zone formation on radial growth of Norway spruce (Picea abies) trees decayed by Heterobasidion annosum s.1. For. Ecol. Manag. 2012, 274, 201-209.

33. Shaw, C.G., III. Is Heterobasidion annosum poorly adapted to incite disease in cool, wet environments? In Proceedings of the Symposium on Research and Management of Annosus Root Rot Disease (Heterobasidion annosum) in Western North America, Monterey, CA, USA, 18-21 April 1989; Otrosina, W.J., Scharpf, R.F., Eds.; Pacific Southwest Forest and Range Experiment Station: Berkeley, CA, USA, 1989; pp. 101-104.

34. Covey, K.R.; Wood, S.A.; Warren, R.J., II; Lee, X.; Bradford, M.A. Elevated methane concentrations in trees of an upland forest. Geophys. Res. Lett. 2012, 39, L15705.

35. Mukhin, V.; Voronin, P. A new source of methane in boreal forests. App. Biochem. Microbiol. 2008, 44, 297-299.

36. Keppler, F.; Hamilton, J.; Brass, M.; Röckmann, T. Methane emissions from terrestrial plants under aerobic conditions. Nature 2006, 439, 187-191.

37. Keppler, F.; Hamilton, J.T.G.; McRoberts, W.C.; Vigano, I.; Brass, M.; Röckmann, T. Methoxyl groups of plant pectin as a precursor of atmospheric methane: Evidence from deuterium labelling studies. New Phytol. 2008, 179, 808-814.

38. Nisbet, R.E.R.; Fisher, R.; Nimmo, R.H.; Bendall, D.S.; Crill, P.M.; Gallego-Sala, A.V.; Hornibrook, E.R.C.; Lopez-Juez, E.; Lowry, D.; Nisbet, P.B.R.; et al. Emission of methane from plants. Proc. R. Soc. B 2009, 276, 1347-1354.

(C) 2015 by the authors; licensee MDPI, Basel, Switzerland. This article is an open access article distributed under the terms and conditions of the Creative Commons Attribution license (http://creativecommons.org/licenses/by/4.0/). 